\title{
Hemorrhagic adrenal cyst
}

\author{
Cisto hemorrágico da glândula adrenal
}

\author{
Elsa Cristina Fontes Pires da Silva ${ }^{1}$, Francisco Viamontez ${ }^{2}$, Vasco Sabino Silva ${ }^{3}$, Artur Andrade ${ }^{4}$, \\ Gonçalo Júlio Neto 2 , Constança de Palma Gomes ${ }^{3}$, Sérgio Neto ${ }^{5}$, Mateus Quitembo ${ }^{5}$, Higino Dimbany 5 , \\ Joaquim Carlos Vicente Dias Van-Dunem ${ }^{6}$, Sandra Maria da Rocha Neto de Miranda, \\ Fernando Bastos ${ }^{6}$, Lemuel Bornelli Cordeiro ${ }^{6}$, Mateus Guilherme ${ }^{8}$
}

\begin{abstract}
The authors present a case of a hemorrhagic adrenal cyst, one of the tumors known in literature as incidentalomas, emphasizing the clinical characteristics, since adrenal cysts or pseudocysts are generally rare and observed by chance during imaging procedures. Traditionally they are classified as pseudocysts, endothelial, epithelial or parasitic cysts. Laparoscopic adrenalectomy has been considered the treatment of choice for benign, functioning or non-functioning adrenal lesions. Small cystic adrenal tumors can be managed conservatively by laparoscopic decortication or marsupialization, but larger cysts should be treated by total or partial adrenalectomy.
\end{abstract}

Keywords: Adrenal gland diseases/diagnosis; Adrenal gland diseases/ surgery; Cysts/diagnosis; Adrenalectomy; Laparoscopy/methods; Case reports

\section{RESUMO}

Os autores apresentam um caso clínico de cisto hemorrágico da glândula adrenal, conhecido na literatura como uma das doenças do grupo dos incidentalomas, enfatizando características clínicas, como cistos e pseudocistos da adrenal, que são raros e geralmente diagnosticados incidentalmente por métodos de imagem. Tradicionalmente, essas lesões são classificadas em: pseudocistos, cistos endoteliais, epiteliais e parasitários. A adrenalectomia laparoscópica vem sendo considerada a conduta cirúrgica de escolha para o tratamento das lesões benignas da adrenal (funcionantes ou não funcionantes). As pequenas lesões císticas da adrenal podem ser manuseadas conservadoramente pela decorticação ou marsupialização laparoscópica; no entanto, os cistos maiores devem ser tratados por meio de adrenalectomia total ou parcial.

Descritores: Doenças das glândulas supra-renais/diagnóstico; Doenças das glândulas supra-renais/cirurgia; Cistos/diagnóstico; Adrenalectomia; Laparoscopia/métodos; Relatos de casos

\section{INTRODUCTION}

Adrenal cysts and pseudocysts are a rare condition usually incidentally diagnosed by imaging methods ${ }^{(1,2)}$. Patients are asymptomatic until the tumor becomes large enough to produce mass effect on adjacent organs. Traditionally, these lesions are classified as pseudocysts or endothelial, epithelial, and parasitic cysts. Pseudocysts are the most common and comprise a heterogeneous group, in which a specific type of apparent vascular origin, characterized by well-defined histological and immunohistochemical findings ${ }^{(3)}$ is the so-called vascular hemorrhagic adrenal pseudocyst.

These pseudocysts show unique microscopic features, as they are composed of a fibrous hyalinized capsule containing clotted blood, residual adrenocortical tissue, and thin-walled vessels without identifiable cystic membranes. This lack of epithelial layer characterizes it as a pseudocyst. They respond strongly to type IV

\footnotetext{
General Surgery Department, Clínica Girassol - Luanda, Angola.

2 Surgery Department, Clínica Girassol - Luanda, Angola.

${ }^{3}$ Imaging Department, Clínica Girassol - Luanda, Angola.

${ }^{4}$ Clinical Director, Clínica Girassol - Luanda, Angola.

${ }^{5}$ Medical Residence Program in General Surgery, Clínica Girassol - Luanda, Angola.

${ }^{6}$ Teaching and Research Department, Clínica Girassol - Luanda, Angola.

${ }^{7}$ Epidemiology Department, Clínica Girassol - Luanda, Angola.

${ }^{8}$ Pathology Department, Clínica Girassol - Luanda, Angola.

Corresponding author: Elsa Cristina Fontes Pires da Silva - Rua Eduardo Mondlane, 59-61 - Caixa Postal 6540 - Luanda, Angola - Phone: (+244) 226698366 - E-mail: elsapiressilva@gmail.com

Received on: May 19, 2011 - Accepted on: Nov 15, 2011
} 
collagen stain, to VIII-AR (related antigen), CD34, and laminine. These immunohistochemical reactions strongly suggest the vascular origin of the lesions. However, there are other hemorrhagic pseudocysts occurring due to trauma and non-traumatic adrenal bleeding, such as stress, tumors, bleeding diathesis or coagulopathies. Those of unknown cause are called idiopathic. However, these pseudocysts are very seldom found in association with cortical neoplasm (carcinoma or adenoma) and pheochromocytoma ${ }^{(1,3)}$.

Laparoscopic adrenalectomy is considered the surgical method of choice to treat benign functioning or nonfunctioning adrenal lesions. Several papers show the advantages of the laparoscopic approach, when compared to open surgery. Besides the improved cosmetics, the technique leads to less bleeding in the intraoperative period, decreased pain in the postoperative period (less use of painkillers), decreased length of hospital stay and lower morbidly rates. Although these papers only comment on the use of laparoscopy for limited-size benign solid tumors, videolaparoscopy increasingly has gradually been used to treat larger lesions including malignant tumors ${ }^{(1,3,4)}$.

Small cystic adrenal lesions can be managed conservatively by laparoscopic decortication and marsupialization, but larger cysts should be treated by partial or total adrenalectomy. A recent study described the removal of a giant adrenal cyst by laparoscopic surgery ${ }^{(5-8)}$.

\section{CASE REPORT}

A 22-year-old black, female patient with a history of trauma (fall from standing height) five days before. After falling she felt abdominal pain, more intense in the right hypochondrium and flank. She reported no nausea, fever and/or mucous and sanguinolent diarrhea. One day before coming to the Girassol Clinic Emergency Room, she still suffered pain and new signs or symptoms were jaundice, postprandial vomiting, anorexia, and inability to pass stool or gas. Upon examination she was conscious, Glasgow 15/15, calm, collaborative, and afebrile. The vital signs were heart rate of $110 \mathrm{bpm}$, thready pulse; blood pressure of $122 / 90 \mathrm{mmHg}$; temperature of $36^{\circ} \mathrm{C}$; respiratory rate of $22 \mathrm{rpm}$. The regional physical exam showed bulging in the right hypochondrium; pain on deep palpation and hepatomegaly $(3 \mathrm{~cm}$ below the lower edge of the ribs) with smooth, regular edges, and little mobility; positive Murphy sign. Laboratory tests upon arrival (blood tests, biochemistry and echography): glucose $129 \mathrm{mg} / \mathrm{dL}$; creatinine 0.6; urea $22 \mathrm{mg} / \mathrm{dL}$; GPT
17; GOT 35; direct billirubin 0.1; platelets - $241 \times 10^{3}$; red blood cells 3.90; $\mathrm{Hb} 8.7 \mathrm{~g} / \mathrm{dL}$; hematocrit 29\%; leukocytes $9.89 \times 10^{3}$ (neutrophils - 84.1\%; lymphocytes - 9.1\%; monocytes $-6.8 \%$ ); Widal test (H: $1 / 320$, O: 1/80); amylase $220 \mathrm{IU} / \mathrm{L}$.

Echography: hepatomegaly with large semiliquid hyperechoic lesion in the right hepatic lobe pressing the right kidney and hepatic portal vessels, measuring 143.8 x $122.6 \mathrm{~mm}$, with septa inside (Figure 1).

Initially, according to tests available, our presumptive diagnosis was an amoebic liver abscess and the patient was hospitalized for workup and treatment. A gradual drop in hemoglobin levels was observed, an average of $1 \mathrm{~g}$ /day. Therefore, an ultrasound-guided fine needle aspiration was performed at the Department of Gastroenterology, obtaining abundant bloody fluid. As this indicated acute abdominal bleeding, we performed an axial computerized tomography (CT) that revealed a large retroperitoneal cystic mass pressing the right kidney and the portal system vessels due to mass effect (Figure 2).

After discussing in the group, the patient was taken to the operating room with a diagnosis of right adrenal hemorrhagic cyst.

Since the patient was hemodynamically unstable, the surgical team decided to perform open adrenalectomy right after the axial CT (Figures 3 to 5).

Figure 6 shows the microscopic image, indicating the capsule and histological tissue.

A right lumbar incision was the best alternative, since this large retroperitoneal mass explained hemodynamic changes mentioned. The patient had an evident and established picture of abdominal compartment syndrome. It is noteworthy that due to the mass size and the compartment effect on the other retroperitoneal structures, the surgeons decided to drain the cyst content

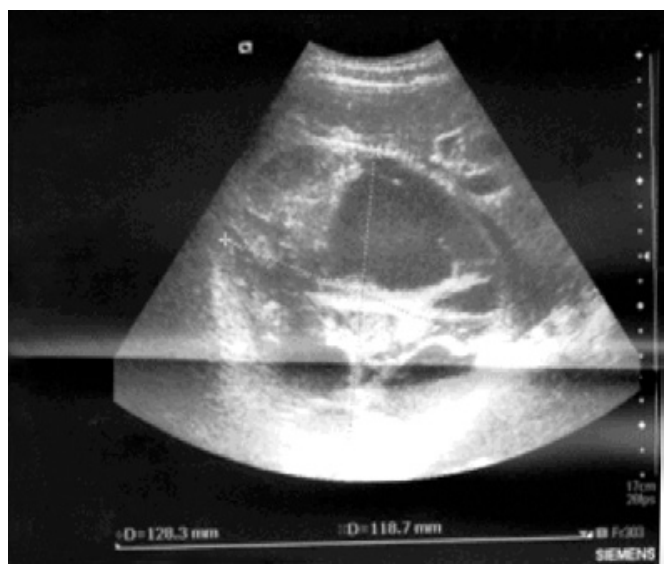

Figure 1. Abdominal echography showing cystic, septated mass 


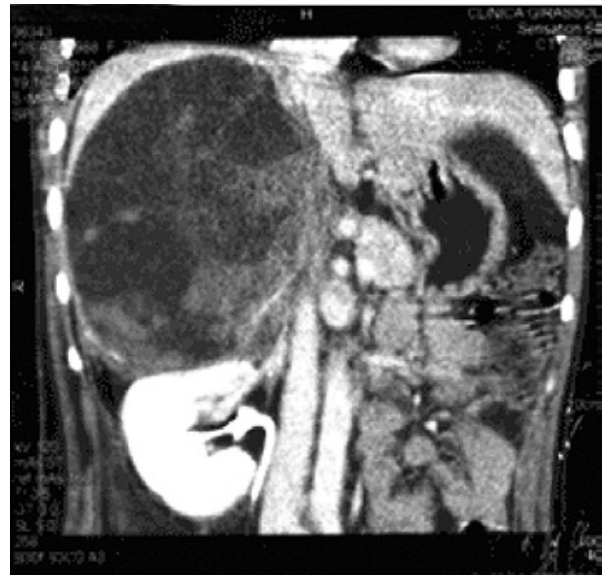

Figure 2. Abdominal axial computerized tomography showing a large mass over the right kidney causing extrinsic compression already causing some mass effect, medically expressed as intra-abdominal hypertension

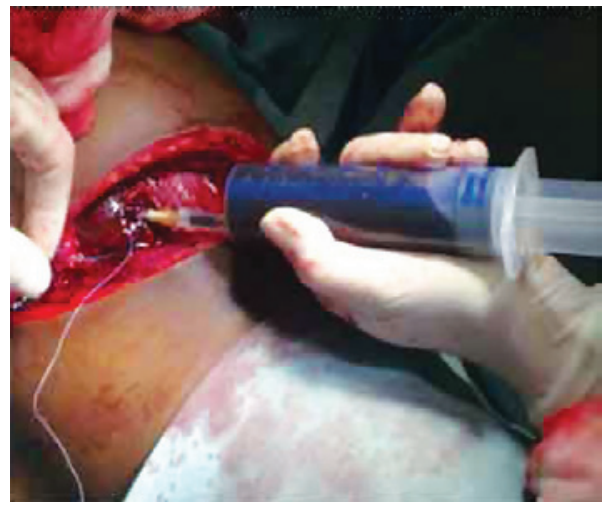

Figure 3. Identification of the retroperitoneal cystic mass and content aspiration

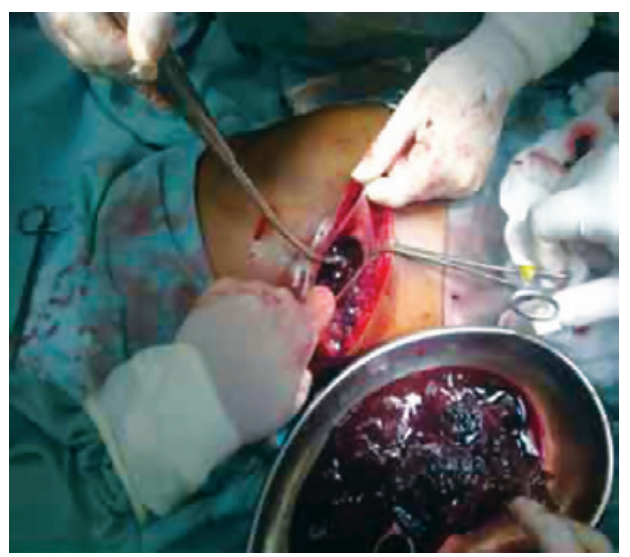

Figure 4. Surgery the cyst capsule is open and the content is aspirated

and to remove it completeltly. A Malecot drain was left in the retroperitoneal cavity for 48 hours after surgery. Because there was little drainage and no suspicious exudate that could be sent for microbiological evaluation and culture, the drain catheter was removed and the patient discharged 96 hours after surgery.

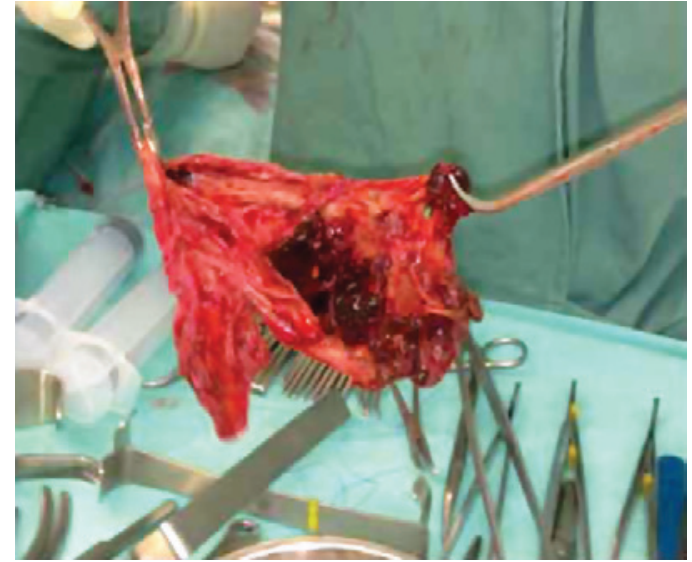

Figure 5. Cystic capsule after exeresis. Note the large lesion

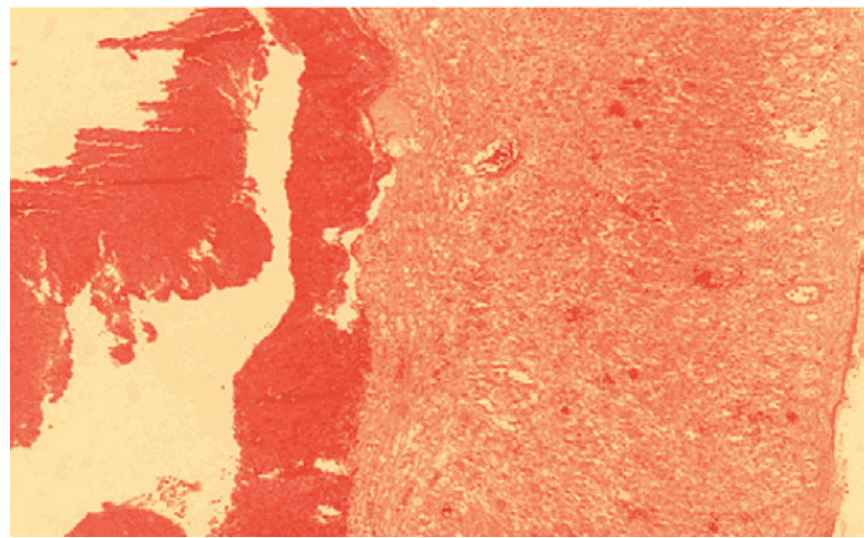

Figure 6. Microscopic image showing the capsule and cystic tissue

\section{DISCUSSION}

The case presented is in accordance with the literature on incidental findings of adrenal cysts and pseudocysts, that is, most diagnoses are made by chance during routine abdominal imaging examinations or resulting from pelvic or abdominal trauma ${ }^{(4)}$. It is not easy to make diagnosis of adrenal hemorrhage, especially due to its unspecific presentation, generally associated to other clinical complications ${ }^{(9)}$.

Initially, the echographic parameter made us thought of an amebic hepatic abcess, since Subsaharian Africa is an edemic region of amebiasis ${ }^{(10)}$. However, repeated and progressive blood loss verified by hemoglobin drop led the surgical team to choose an invasive procedure, the ultrasound-guided percutaneous biopsy revealing a serous and sanguinolent exsudate. Considering the dubious interpretation, clinical worsening, abdominal distention and pain, an axial $\mathrm{CT}$ of the abdomen was decisive for diagnosing the right adrenal hemorhagic cyst $^{(11)}$.

Although the best references in the literature state that video-guided surgery is the best treatment available 
for adrenal cysts ${ }^{(12,13)}$, and we fully agree, the learning curve in trauma situations and the intra-abdominal mass effect, the retroperitoneal localization and the fact that our results are better with open surgery had to be taken in account. Thus, one of the aims of this case report is the exchange of ideas about the best approach.

\section{CONCLUSION}

An adrenal hemorhagic cyst case in which surgical ressection was a safe option leading to a good outcome was reported.

\section{REFERENCES}

1. Melo MA, Lucena MT, Cartaxo HO. Pseudocisto adrenal hemorrágico gigante tratado por acesso videolaparoscópico. Rev Bras Videocir. 2005;3(4):208-15.

2. Gagner M, Lacroix A, Bolte E. Laparoscopic adrenalectomy in Cushing's syndrome and pheochromocytome. N Eng J Med. 1992;327(14):1033.
3. Martins DL, Baroni RH, Blasbalg R, Viana PC, Bezerra RO, Donato Jr F, et al. Avaliação por ressonância magnética dos tumores de adrenal com correlação histológica. Radiol Bras. 2008;41(1):55-62.

4. Chapuis Y. Laparoscopic versus Young-Mayor open posterior adrenalectomy: a case control study of 100 patients. Chirurgie. 1998;123(3):322-3.

5. Sabiston tratado de cirurgia: as bases biológicas da prática cirúrgica moderna 17a ed. Rio de Janeiro: Guanabara Koogan; 2003.

6. Gordon H. Distúrbios da glândula adrenal. In: Harrison medicina interna. 17a ed. Rio de Janeiro: McGraw-Hill; 2008. Vol II, Parte 13, Secção 1. p. 2213-40.

7. Nunes LF, Mello EL, Corrêa JH. Análise crítica da adrenalectomia videolaparoscópica. Rev Bras Cancerol. 2003;49(4):215-20.

8. Marcelino J, Dias J, Martins F, Lopes T. Incidentaloma da glândula supra-renal. Avaliação e atitude terapêutica. Acta Urol Portuguesa. 2000;17(4):35-40.

9. Simon DR, Palese MA. Clinical update on the management of adrenal hemorrhage. Curr Urol Rep. 2009;10(1):78-83.

10. Hotez PJ, Kamath A. Neglected tropical diseases in sub-saharan Africa: review of their prevalence, distribution, and disease burden. PLoS Negl Trop Dis. 2009;3(8):e412.

11. Pradeep PV, Mishra AK, Aggarwal V, Bhargav PR, Gupta SK, Agarwal A. Adrenal cysts: an institutional experience. World J Surg. 2006;30(10):1817-20.

12. Simforoosh N, Majidpour HS, Basiri A, Ziaee SA, Behjati S, Beigi FM, et al Laparoscopic adrenalectomy: 10-year experience, 67 procedures. Urol J. 2008; 5(1):50-4.

13. Amarillo HA, Bruzoni M, Loto M, Castagneto GH, Mihura ME. Hemorrhagic adrenal pseudocyst: laparoscopic treatment. Surg Endosc. 2004;18(10):1539. 